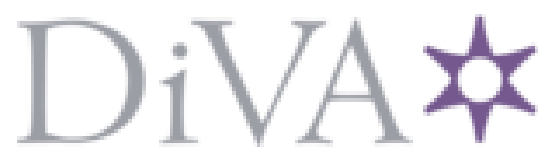

http://www.diva-portal.org

This is the published version of a chapter published in Environmental Governance of the Baltic Sea.

Citation for the original published chapter:

Karlsson, M., Gilek, M. (2016)

Governance of Chemicals in the Baltic Sea Region: A Study of Three Generations of Hazardous Substances.

In: Gilek, M. et al. (ed.), Environmental Governance of the Baltic Sea (pp. 97-123). Springer Open MARE Publication Series

N.B. When citing this work, cite the original published chapter.

Permanent link to this version:

http://urn.kb.se/resolve?urn=urn:nbn:se:sh:diva-29779 


\title{
Chapter 5 \\ Governance of Chemicals in the Baltic Sea \\ Region: A Study of Three Generations of Hazardous Substances
}

\author{
Mikael Karlsson and Michael Gilek
}

\begin{abstract}
This study zooms in on public governance in the Baltic Sea region of three generations of notorious hazardous substances, namely, PCBs, PBDEs and PFOS/PFOA. Following regulation, PCB concentrations in the Baltic Sea have decreased substantially although they are still above pre-industrial levels. PBDE levels have also decreased in some places, but they too are well above targeted levels, whereas the situation for PFOS and in particular for PFOA has hardly improved at all. In the case of PCBs, while comprehensive measures took long to implement, initial preventive measures were taken early based on the precautionary principle. This contrasts with the cases of PBDEs, PFOS and PFOA, where the burden of proof on policy-makers has been high and hence caused severe delays in policymaking. There has, however, generally been a positive interplay in all three cases between the EU, which has legislated, and HELCOM, which has taken the role of concept and agenda setting. While environment-oriented policies, such as the Ecosystem Approach to Management under MSFD and BSAP, have grown in importance over time, polluter-oriented chemical legislation has been more important when it comes to final decision-making. Nevertheless, the general response has been reactive rather than proactive, and there is no indication that society responds faster today than in the past, at least not given the fact that awareness, experience and knowledge are greater today than a few decades back. Based on that insight, the article discusses various options for improving governance.
\end{abstract}

Keywords PCB - Brominated flame retardants - Fluorinated substances • Ecosystem approach to management $\bullet$ Precaution

M. Karlsson $(\varangle) \cdot$ M. Gilek

School of Natural Sciences, Technology and Environmental Studies, Södertörn University, 14189 Huddinge, Sweden

e-mail: mikael.karlsson@2050.se; michael.gilek@sh.se 


\subsection{Introduction}

It is well known that tens of thousands of man-made chemical substances are used by industries in the making of various products in the Baltic Sea area. Hundreds of these, known to have inherent hazardous properties, are emitted and present in the marine environment, both in the sea and in living organisms in and around the sea, including in humans (HELCOM 2010a; Lyons 1999). The negative consequences of these substances on various species have been well documented in the case of the Baltic Sea, including reproductive disorders in marine mammals (Bergman 2007) and imposex in snails (Santillo et al. 2001). In other cases, the long-term consequences are more difficult to interpret, for example, the fact that newborns of mothers on the East Coast of Sweden, who consume a relatively high amount of contaminated fish, weigh significantly less than newborns on the West Coast (Rylander et al. 2000). Most likely, the full picture of consequences of hazardous substances in the marine environment is still emerging.

In fact, when it comes to understanding the total risks of real life exposure to the very complex mixture of hundreds or more industrial chemicals in the Baltic Sea, there are huge information gaps. This is basically due to lack of knowledge and data on properties and exposure conditions for the vast majority of substances (Allanou et al. 1999; Gilbert 2011; Rudén and Hansson 2010) and in particular the adverse consequences of combinations of these substances (Kortenkamp et al. 2009). On top of this complex pollution situation with extreme levels of scientific uncertainty, a complex and fragmented governance system consisting of multi-level, multisector and multi-actor interactions escalates the challenges associated with environmental policy objectives. That the Baltic Sea ecosystem in addition is more vulnerable to pollution than most other sea areas (Magnusson and Norén 2012) is not making the task easier.

To cope with the problems and risks of chemical pollution, a number of governance structures and strategies have been put in place, aimed at what has been termed a "Baltic Sea with life undisturbed by hazardous substances" (HELCOM 2007). However, in spite of quite successful mitigation efforts in relation to some pollutants, overall goals are far from being realised (HELCOM 2010a; MMB 2012) and the resulting costs of chemical contamination can be very high (KEMI 2013a; NCM 2004; UNEP 2013). At the EU level, for example, it has been roughly estimated in one study that exposure to endocrine disrupting chemicals costs 13-31 billion Euros annually (Jensen 2014), whereas the costs today of impaired male reproduction have been calculated in another study to reach above 1.2 billion Euros, with variations up and down depending on the assumptions made (NCM 2014). Over time, the political landscape, mitigating measures and environmental governance approaches in place have all evolved. In the 1960s, "polluter-oriented" approaches emerged, commonly focusing on national command and control of point sources, which gradually were complemented with "environment-oriented" approaches, based on broader and ecologically more holistic perspectives (Karlsson et al. 2011). Under the former approach, in the "sphere" of, for instance, chemicals policy, preventive measures were often balanced by compromises based on 
technological and economic parameters, such as in requirements for best available technology. Such measures still constitute important parts of environmental law in the Baltic Sea region, for example, in legislation on the use of chemical substances, such as the REACH regulation (EC 2006a) of the European Union (EU). In the latter environment-oriented "sphere", the starting point is rather health and ecosystem parameters, which is evident, for instance, in the setting of environmental quality standards and in criteria and indicators for Good Environmental Status under the EU Marine Strategy Framework Directive (EC 2008a).

This development in law and practice has gone hand in hand with new theories on environmental policy, underlining the need for broad governance studies and strategies. While the governance concept has been described in various ways (Adger and Jordan 2009; Kooiman 2003; Pierre and Peters 2005; Young 1994), a common core recognises the transfer of government authority upwards to international institutions, sideways to non-governmental actors and downwards to local actors (Kern and Löffelsend 2008). In the multi-country, multi-sector, multi-risk and multistakeholder environment of the Baltic Sea area, broad governance measures are not only taking place but are also considered normatively desirable (Joas et al. 2008), not least when it comes to the prevalent call for an 'ecosystem approach to management' (EAM) (Backer et al. 2010; Curtin and Prellezo 2010; Karlsson et al. 2011; Murawski 2007; Österblom et al. 2010). EAM is integral to the Convention on Biodiversity (UN 1992) as well as in the work of HELCOM, the executive body under the Helsinki Convention (1974), where it has been defined as (HELCOM and OSPAR 2003):

\footnotetext{
"the comprehensive integrated management of human activities based on the best available scientific knowledge about the ecosystem and its dynamics, in order to identify and take action on influences which are critical to the health of marine ecosystems, thereby achieving sustainable use of ecosystem goods and services and maintenance of ecosystem integrity". The application of the precautionary principle is equally a central part of the ecosystem approach.
}

Under this environment-oriented governance approach, which recognises complexities in both natural and social systems, all relevant and interlinked systems and parameters are supposed to be considered across scales and sectors over time and in the light of the precautionary principle. Nowadays, EAM is expressed in both policy, for example, the Baltic Sea Action Plan (HELCOM 2007), and law, for example, the Marine Strategy Framework Directive (EC 2008a).

This case study on public governance of chemicals in the Baltic Sea investigates three key examples from three generations of halogenated organic industrial substances, namely, PCBs (chlorinated), PBDEs (brominated) and PFOS/PFOA (fluorinated). This choice of sub-cases has been made in order to allow for an in-depth analysis of how public governance has evolved under different periods and political systems, with varying degrees of uncertainty and controversies. In doing so, the article describes the co-evolution of risk and governance in each sub-case, with a focus on two key bodies for environmental policy in the Baltic Sea region - the EU and HELCOM. The ultimate aim is to elaborate on potential strategies for improving the fulfilment of environmental objectives at hand. More specifically, the study addresses the following questions: 
1. Which measures - such as legislation, recommendations and policies - have the EU and HELCOM taken to manage PCBs, PBDEs and PFOS/PFOA; how do these relate to risk assessment, scientific uncertainty and controversies; and what governance outcomes can be identified?

2. Which governance approaches - such as risk-based polluter-oriented command and control, or EAM, including the precautionary principle - have been applied in each of the sub-cases?

3. What can be learnt from the past and present, and which strategies can be identified for potentially improving risk governance of chemicals in the Baltic Sea region (BSR)?

The focus on EU and HELCOM, based on the insight that these institutions are the most important ones for the governance of chemicals in BSR (Karlsson et al. 2011), means that measures at national or other levels, as well as voluntary measures, will not be studied in any detail. Furthermore, the study centres on industrial chemicals in general and not on specific groups of chemicals or products, such as pharmaceuticals or toys, since the associated risks and regulations in such cases often deserve specific attention. In addition, the emphasis is placed on initial science-policy relations, and on broader policies and general legislation, rather than on the often very detailed and diversified regulations that develop once a problem has been commonly recognised and measures have been institutionalised in society along products' and substances' life cycles.

The study is primarily based on a review of documents and literature, but also on a series of in-depth interviews with a number of stakeholders. The documents studied were peer-reviewed scientific publications on problems and management in the area, so-called grey literature, such as reports and other types of publications from non-governmental and governmental agencies and institutions working on environmental governance in BSR, and political documents. The latter consisted of laws, policies, plans, assessments and various types of documents pertaining to strategies and management tools, mostly at EU and international levels. Examples include:

- EU: the Water Framework Directive (EC 2000), the Marine Strategy Framework Directive (EC 2008a) and the REACH regulation (EC 2006a), together with several technical risk assessment documents (e.g. EEC 1993; European Commission 1994).

- HELCOM: the Baltic Sea Action Plan (BSAP) (HELCOM 2007) under the Helsinki Convention $(1974,1992)$, several politically adopted recommendations and technical documents and reports for monitoring and assessment.

The in-depth interviews were carried out as part of the broad RISKGOV project and have been documented and reported elsewhere (Karlsson et al. 2011; Udovyk et al. 2010). A total of 22 semi-structured interviews, with open-ended questions, were conducted with scientists, politicians and journalists, as well as other actors in HELCOM institutions and national and EU authorities. For this study, the general results from the interviews are foremost used to structure the analysis and find the broader patterns over time in relation to the sub-cases studied.

In what follows, we present an overview of the development of governance in BSR over time, after which the three generations of sub-cases are detailed. Each 
result section starts with a problem presentation and a description of the more specific governance measures taken in the EU and by HELCOM, respectively, and is followed by an analysis of trends and approaches. In doing so, the policies, laws and other tools discussed are brought up chronologically and related to each case. The article ends with a discussion on potential roads ahead that may promote policy objectives in place.

\subsection{Governance of Industrial Chemicals in the Baltic Sea Region over Time}

Chemical risks in BSR are dealt with at local, regional, national, EU and international levels. Measures taken at the local level, being largely those of implementing law, are dependent on decisions taken at the national level and, in the case of traded products, on supranational agreements, made either within the EU or internationally. Governance structures at high levels in particular have evolved and changed substantially since the mid-1900s, the time period when industrial chemicals increasingly have come into use.

When the debate on chemical risks and their governance was initiated in the early 1960s, West Germany was the only country in BSR that was then a member of what was known as the European Community (EC). It was only a decade later or so that another Baltic Sea country, Denmark, joined the EC. At that time, the EC had no more than a rudimentary chemicals policy. What was in place in parallel was the Helsinki Convention (1974) for the protection of the Baltic Sea, which entered into force in 1980, as a binding framework agreement for the seven contracting parties. The convention aimed to control all types of pollution and imposed various obligations on parties to counteract hazardous substances. The Soviet Union was a part to the convention and dominated the eastern shores of the Baltic Sea. In spite of the cold war, however, the HELCOM operative body of the convention managed to adopt a large number of 'recommendations' over the coming decades, one example being for hazardous substances (Selin and VanDeveer 2004).

Eventually, the Berlin Wall and the Soviet Union fell, and soon thereafter, the convention was amended and other (Eastern European) countries and the EC joined the cooperation (Helsinki Convention 1992). The revised convention was extended and strengthened with specific and technical provisions and action points addressing the prevention and control of pollution including chemical pollution. The precautionary principle was explicitly included, even if the concept was referred to already in a 1988 ministerial meeting, and precautionary measures were taken already from the start, e.g. by recommending phase-out of substances not fully scientifically proven to cause damage (Pyhälä et al. 2007).

In 1995, Finland and Sweden joined the EU. Most of the countries of the Baltic Sea shoreline were then part of the EU. Due to a treaty revision in the mid-1980s (EC 1986), the EU had set explicit treaty-based environmental objectives, which over time led to a more comprehensive - and binding - environmental legislation in the union, including in the field of chemicals and the marine environment. It is 
important to point out that the EU has the power to enforce various stipulations if not followed by Member States, something that is not the case under the Helsinki Convention despite its binding character. In fact, the European Court of Justice can in some cases even decide to impose economic sanctions on Member States that do not comply with legislation agreed upon in common.

Ten years later in 2004 when the EU was enlarged, Russia was the only Baltic country that remained outside the EU (i.e. Poland and the three Baltic States became EU members). Since then, the EU has steadily introduced more policies that apply to the presence of chemicals in the marine environment of BSR. These include laws such as the environment-oriented Water Framework Directive and Marine Strategy Framework Directive, and the polluter-oriented REACH regulation for industrial chemicals, as well as the EU Strategy for BSR (European Commission 2009). Similar developments also took place under HELCOM, which, besides further recommendations relating to chemicals, adopted the Baltic Sea Action Plan in 2007 (HELCOM 2007). The plan has several objectives, including that life in the Baltic Sea should be 'undisturbed by hazardous substances'. It also underlines the need to apply the EAM. In the hazardous substance segment of BSAP, four 'ecological objectives' are set: concentrations of hazardous substances close to natural levels, all fish safe to eat, healthy wildlife and radioactivity at pre-Chernobyl level. These targets are then further operationalised by, for instance, various indicators.

In addition to formal governance under HELCOM and the EU, a wide array of actors and networks has strived since decades to protect the Baltic Sea environment. Among these are a number of national and international NGOs, as well as various business, city and university networks, which collaborate on marine and other governance issues.

In summary, the governance structures have shifted substantially over time in BSR both under the Helsinki Convention and within the EU, with increasingly more attention being given to an environment-oriented perspective. The geopolitical changes of the last few decades have allowed for improved collaboration and international governance structures that potentially are more capable than in the past of coping with environmental problems and risks in the Baltic Sea at an international level. In what follows, the selected three sub-cases and generations (with respect to broader societal recognition, debate and policy-making ${ }^{1}$ ) of hazardous chemicals that occur in the region, and how they are governed, will be described and analysed.

\subsection{The First Generation, Chlorinated Organic Substances: PCBs}

Halogenated organic substances are in general particularly problematic man-made chemicals. They are released and can be found in living organisms all around the globe, from Alaska in the North to the summits of European mountains to

\footnotetext{
${ }^{1}$ As will be shown, scientific studies showing or indicating problems often came earlier (see also EEA 2001, 2013).
} 
deep-water fish in the South Atlantic (Burkow and Kalleborn 2000; Carrera et al. 2001; Looser et al. 2000). The use of chlorinated organic chemicals was questioned by scientists as far back as the 1950s (Linduska 1953) and gave rise to international public concern after the publication of Rachel Carson's 'Silent Spring' in 1962. While the substances in focus then were often pesticides designed to be toxic, for example, DDT, the widely used ${ }^{2}$ group of polychlorinated biphenyls, PCBs, was not intended to have any toxic effects. Despite that, and long after its original introduction in 1929, scientists revealed PCB in the environment in the 1960s (Jensen 1966). This was the case because PCBs have persistent and bioaccumulative properties. These properties, in combination with the substance group's toxic properties (e.g. carcinogenicity, reproductive toxicity, environmental toxicity), led to severe adverse effects in various organisms and ecosystems. In the Baltic Sea area, for example, white-tailed eagles, grey seals, ringed seals and otters were among the species severely affected (Bergman and Olsson 1985; Helander 1983; Roos et al. 2001). Findings pertaining to new types of neurological effects on humans were reported as late as in $2001,{ }^{3}$ which illustrates the not seldom long time gap between the initial use of a substance and strong evidence on chronic health effects (Schantz et al. 2001).

\subsubsection{EU Policy}

The EU is clearly a dominant actor in BSR with regard to policy. Legislation within the EU is divided into a primary treaty level and secondary directives, regulations and decisions. The treaties set out the basis for the Council's and the Parliament's co-decisions on secondary law, as well as stipulate legal principles - in the field of the environment, for instance, precaution and that the polluter should pay. Up to the mid-1980s, laws relevant to the environment generally aimed to harmonise national legislation in order to promote the free movement of, for example, products of various kinds. Since the Single European Act (EC 1986), however, the EU has been mandated to legislate also in explicit order to protect the environment, an area where laws set minimum requirements that Member States may choose to make more stringent. If the treaty basis on the other hand is market harmonisation, it is quite difficult for a Member State to deviate from the common provisions, unless, for example, new scientific evidence shows that measures are needed to attain environmental objectives. To what extent that is possible is ultimately decided in the European Court of Justice in case of a trial in which treaty-based principles on environmental protection as well as, e.g. proportionality are considered.

When chemicals policy emerged in the European Community in the 1960s, with, for example, a directive (EEC 1967) on classification and labelling of industrial chemicals, the aim was market harmonisation. Some years later, another directive

\footnotetext{
${ }^{2}$ World production, for example, in the 1980s was in the order of millions of tonnes.

${ }^{3}$ Human toxic effects under some exposure conditions have been reported at least since the 1930s though; see EEA (2001).
} 
(EEC 1976a) provided ground for restrictions on substances and preparations, in themselves or in products, but a ban on the use of PCBs was not included until 1985 (EEC 1985) when the EC in BSR included West Germany and Denmark. Nowadays, this ban is incorporated in the REACH regulation (EC 2006a) for industrial chemicals, which has replaced much of the earlier legislation. ${ }^{4}$

Besides for the general ban, a number of other policy and regulatory tools targeting PCBs have been developed, including a directive governing disposal of PCB that aims for a phase-out of equipment with PCB by 2010 (EC 1996), a 'Strategy for dioxins, furans and $\mathrm{PCB}^{\prime 5}$ (European Commission 2001) and recommendations and regulations for maximum levels of certain contaminants in foodstuff. Compared to directives, which Member States themselves are responsible for achieving, running the risk of ending up in the European Court of Justice in case of non-compliance, regulations are directly binding all over the EU, i.e. they have a stronger and more immediate legal power. PCBs were mentioned in the food contamination regulation of the EC (2001), but limit values came first with EC (2006b) for dioxin-like PCBs and EC (2011) for non-dioxin-like PCBs. However, Sweden, Finland and Latvia have all argued for and been granted derogations, which at the time of writing were still in place, meaning that it is allowed in these countries to sell contaminated fish to the national populations at large, in spite of opposing views from expert agencies (EC 2001; SNFA 2011).

When it comes to the presence of PCBs in the environment as such, the general 1976 directive on limit values for dangerous substances in water (EEC 1976b) did not include PCBs specifically. ${ }^{6}$ Neither did the original Priority Substances Directive (EC 2008b), sometimes referred to as a daughter directive to the Water Framework Directive (EC 2000), which sets environmental quality standards for 33 substances or groups of substances. Recently though, amendments of the WFD and the Priority Substance Directive (PSD) included dioxin-like PCBs. In the case of PSD, Member States have to implement applicable environmental quality standards by 2018 in order to reach a good surface water chemical status by 2027 at the latest, by the means specified in the Water Framework Directive (EU 2013).

The Marine Strategy Framework Directive (EC 2008a), which is based on EAM and the precautionary principle, includes a focus on what the European Commission has decided to call 'contaminants' (according to the so-called Descriptor 8), which to a large extent are priority substances in WFD and PSD (EU 2010a), including PCBs. Member States are responsible to further define more precise targets for these hazardous substances as well as programmes to achieve a ' $g o o d$ environmental status' by 2020. The Baltic Sea is one region in which this has to be done (EC

\footnotetext{
${ }^{4} \mathrm{~A}$ general ban is also included in another EU Regulation, which aims to implement the Stockholm Convention on persistent organic pollutants, one of which is PCBs (EC 2004).

${ }^{5}$ The strategy lists all EU measures that by then were taken to mitigate PCB pollution (not all of these are discussed in this study), and the strategy was followed up in 2004 and 2007 (for the latter, see: http://eur-lex.europa.eu/legal-content/EN/TXT/PDF/?uri=CELEX:52007DC0396\&from $=\mathrm{EN})$.

${ }^{6}$ Organohalogens were referred to in general though.
} 
2008a). When it comes to the Baltic Sea, HELCOM has established a link between MSFD and the Baltic Sea Action Plan and coordinates the national implementation by EU Member States (HELCOM 2010b).

\subsubsection{HELCOM Policy}

Under the 1974 Helsinki Convention, organochlorinated and several other hazardous substances became targets for HELCOM's activities. Since then, PCBs have been in focus for various monitoring (in a coordinated manner since 1979), risk assessment and risk management measures. Monitoring and assessments under HELCOM are following a specific strategy with, for example, objectives, principles and indicators (HELCOM 2013a), and the contracting parties as well as various expert groups and scientific committees participate in the work. A set of PCBs belonging to the so-called HELCOM 'core indicators' for hazardous substances under the Baltic Sea Action Plan (HELCOM 2007, 2013), and their trends are monitored over time (Boalt et al. 2013).

In terms of risk management, HELCOM measures commonly consist of various Recommendations to the parties of the convention. Regarding PCBs, the 1974 Convention mentioned them explicitly. Based on a 1981 ICES environmental assessment, HELCOM adopted a Recommendation (3/1) in 1982 that contracting parties should, allowing for some exemptions, prohibit the introduction of new products containing PCBs and develop national regulations for reducing discharges from existing sources (HELCOM 1982). In 1985, another Recommendation (6/1) underlined the urgency to do so and requested the parties to stop production and marketing of PCBs from 1987, more specific action against existing sources as well as the use of more specified reporting procedures (HELCOM 1985).

Due to the discovery of elevated concentrations of numerous hazardous substances in the Baltic Sea in the 1980s, a 1988 Ministerial Declaration took a broad approach and set a target to reduce the total discharges of the most harmful substances by around $50 \%$ by 1995 (HELCOM 1988). This led to a list of such substances in 1991, initially covering 46 substances and groups of substances, 1 being the large group of organohalogens (Selin and VanDeveer 2004).

Similarly, the 1992 amendment of the Convention required the Contracting Parties to take a broad approach in order 'to prevent and eliminate pollution of the marine environment of the Baltic Sea Area caused by harmful substances from all sources' (Helsinki Convention 1992, Article 5). Annex 1 contained general principles for 'harmful substances' and listed both priority groups for action and 'banned' substances, where it was stated (Part 2.2) that in 'order to protect the Baltic Sea Area PCBs shall be banned for all uses, except in existing closed system equipment until the end of service life or for research, development and analytical purposes in the Baltic Sea Area and its catchment area.'

Furthermore, based on a 1996 agreement taken in the Council of the Baltic Sea States (CBSS 1996), another HELCOM Recommendation (19/5) in 1998 set a 
target to continuously reduce discharges, emissions and losses of hazardous substances towards cessation by 2020 , so as to reach background values for naturally occurring substances and close to zero concentrations for man-made substances (HELCOM 1998). By then, 280 substances were listed as 'potential substances of concern', of which 43 were prioritised for 'immediate action', including PCBs. Compared to previous agreements that focused on upstream measures, the starting point here was environmental quality and close to zero tolerance for pollution.

The PCB problems remained in the 2000s, and a new Recommendation (25/1) on PCBs was adopted, superseding a previous one (6/1), with updated calls on the Parties and further specifications on measures relating to, for example, destruction and decontamination (HELCOM 2004). In the 2007 Baltic Sea Action Plan, 11 of the most problematic substances, including dioxin-like PCBs, were listed as being of 'specific concern' to the Baltic Sea, and for these, ecosystem-based targets have been developed in order to reach the objective of a 'life undisturbed by hazardous substances'.

Finally, also the broad 1998 Recommendation (19/5) was replaced in 2010 with a new general Recommendation (31E/1) on 'Implementing HELCOM's objectives for hazardous substances' (HELCOM 2010c). Here, the attached guiding principles, definitions and strategy were updated and modernised. For instance, there are explicit references to both the EU REACH Regulation and the UN Global Harmonised System for classification and labelling of chemicals. The precautionary elements are more obvious, including a definition (and linked to priority setting and mitigating measures) of 'hazardous' to include substances that are very persistent and very bioaccumulative (i.e. without necessarily being toxic). PCBs are among the listed priority substances.

\subsubsection{Analysis of Measures Taken and Approaches Applied}

Due to the various regulatory initiatives, $\mathrm{PCB}$ concentrations in the Baltic Sea marine environment have decreased substantially over time, even though they have stabilised at levels that still are significantly above those of pre-industrial era. The populations of some of the wildlife species that previously were seriously threatened such as the three Baltic Sea seal species and the white-tailed eagle have consequently increased. ${ }^{7}$ However, according to HELCOM, the general situation is still considered as 'moderate or bad' (Boalt et al. 2013), and the objective to reach an environment with levels of man-made substances close to zero is far from achieved, also with respect to PCBs. For example, the 1988 goal to half discharges of the most harmful substances by 1995 had by 2001 only been achieved for less than two-thirds of the substances on the list. However, the target had been achieved for PCBs (Selin and VanDeveer 2004). Moreover, despite precautionary measures taken, the total remediation and waste management costs for PCBs continue to be very high. In

\footnotetext{
${ }^{7}$ In the case of the white-tailed eagle, artificial feeding for three to four decades played a key role in preventing national or regional extinction.
} 
Sweden alone, from 1971 to 2018, the costs were estimated to be 380-480 million euros. Corresponding EU figures amounted to 15-75 billion euros (NCM 2004).

Looking back, it is clear that the legally stipulated practical measures against PCB in the 1970s in some Baltic Sea countries were taken years before there was comprehensive conclusive evidence on causal links between PCB contamination and the various adverse effects observed in the Baltic Sea environment. In spite of some but much earlier evidence on certain negative health effects of PCB exposure (EEA 2001), it can therefore still be said that these policies were precautionary.

Moreover, it is clear that HELCOM has been an important body for much of the policy-making with regard to PCBs. However, forerunner countries (e.g. Sweden and Germany $^{8}$ ) acted earlier and to some extent independently of HELCOM. But laggard countries (e.g. Poland) did not act until they were applicants to or members of the EU. The forerunners have foremost used HELCOM to push for measures in other countries, by insisting on and making use of both recommendations and associated monitoring and risk assessment activities. Conversely, HELCOM has hardly played a decisive role for chemicals policy in laggard countries, for instance, in Poland, which seemingly (although it is important to note that data gaps for Russia give rise to significant uncertainty) stands for most of the PCB emissions (COHIBA 2012), and where the societal debate on chemicals issues is largely absent (Eriksson et al. 2010a).

Compared with HELCOM, policy measures in the EU came later, but the impact of EU measures on national policy was significant, including in laggard countries. Much therefore speaks for the regulatory power of the EU to ultimately have been of higher importance for the abatement in practise of PCB problems, than what the power of HELCOM has been. However, HELCOM has been instrumental in acting early and setting the agenda, in monitoring and assessing environmental quality and in showing - at least initially - through its various recommendations the importance of the regulatory way forwards. It is far from sure that the EU would have acted as it did without this pioneering, catalytic and facilitating role of HELCOM. In addition, HELCOM in contrast to the EU includes Russia, where a number of the otherwise restricted hazardous substances are still permitted (COHIBA 2012).

Moreover, HELCOM has taken a leading role in developing environmentoriented approaches. This has been the case with the 1992 Helsinki Convention, the zero concentration objective adopted in a Recommendation in 1998 and in the joint HELCOM-OSPAR EAM-statement in 2003. Similarly, the precautionary principle has definitely and for a longer time been playing a more central role in HELCOM than in the EU. More recently, the EU has also institutionalised EAM, for example, in MSFD. Considering the links and increasing coordination of implementation between MSFD and BSAP, it seems plausible that both institutions will strive for a broader use of EAM, even if the EU at the same time will keep its strongly polluteroriented REACH regulation.

All in all, it seems well motivated to conclude that in this PCB sub-case, HELCOM and the EU have interplayed in a positive way, the former mainly initiat-

\footnotetext{
${ }^{8}$ In, e.g. Germany, Monsanto and Bayer stopped PCB production by 1977 and 1983, respectively, which might have facilitated some of the regulation.
} 
ing measures and being an agenda-setter and conceptual pioneer and the latter as a powerful and adaptive legislator. It must be underlined though that this relates to policies for PCB, one of the most infamous pollutants in the world, and generalisations cannot be made to effect and effectiveness for chemicals policy at large. On the contrary, it can be concluded that the regulatory response even in this notorious case has been far from rapid.

\subsection{The Second Generation, Brominated Organic Substances: PBDEs}

A second group of industrial organohalogens is the brominated, and within this group, not least flame retardants and particularly polybrominated diphenyl ethers (PBDEs) have been much discussed since at least the 1980s. Brominated flame retardants (BFRs) have been frequently used since the 1950s as additives in plastic polymers in, for example, textiles and electric and electronic products. Since PBDEs generally are persistent and bioaccumulative, they have increasingly been detected in wildlife, humans and the wider global environment since the 1980s (Birnbaum and Staskal 2004; Law et al. 2006; Nyberg et al. 2013a; de Wit 2002). There are still knowledge gaps when it comes to the specific properties and risks of most BFRs. However, so-called lower brominated ${ }^{9}$ PBDEs have since long been shown widespread in ecosystems, including in the Baltic Sea environment (Airaksinen et al. 2014; Szlinder-Richert et al. 2010), and are known to negatively affect hormone, reproductive and neurological systems in mammals (Birnbaum and Staskal 2004; Darnerud et al. 2001; Eriksson et al. 2001, 2002; Ilonka et al. 2000). More recent studies have shown great concerns regarding human health effects as well (Eskenazi et al. 2013; Herbstman et al. 2010; Ward et al. 2014). Higher brominated PBDEs, such as decaBDE, were initially not considered as problematic, and many industry stakeholders in fact claimed that decaBDE did not bioaccumulate due to the molecule's comparatively large size (ECB 2002). But this was falsified when Lindberg et al. (2004) showed the presence of decaBDE in eggs of the peregrine falcon. Other studies have pointed out that decaBDE can degrade in the environment to lower brominated PBDEs (Gerecke et al. 2005; Stapleton et al. 2004).

\subsubsection{EU Policy}

Scientific findings from the 1980s and onwards did not lead to any potential risk mitigating measures in the EU until the mid-1990s when some BFRs were placed on so-called priority lists for risk assessment of existing substances (EEC 1993).

${ }^{9} \mathrm{PBDEs}$ with not more than five bromine atoms, such as pentaBDE. 
Among these were pentaBDE and octaBDE. The initial risk assessment for pentaBDE recognised the need for risk reduction measures (ECB 2000); additional studies highlighted further problems, as exemplified above. Based on the risk assessment, the EU in 2004 eventually prohibited use of not only pentaBDE but also octaBDE (EC 2003a). The additional regulation of decaBDE was intensively debated, but the outcome of the European Parliament and Council co-decision procedure, despite that the former body wanted a ban, was that the substance was not banned. ${ }^{10}$ In spite of that, political and legal processes concerning implementation of the ROHS directive on electric and electronic products (EC 2003b), which banned pentaBDE and octaBDE from 2006, led to a 2008 ban of decaBDE as well (ECJ 2008; Eriksson et al. 2010a, 2010b). ${ }^{11}$

In parallel, the 2003 WEEE directive (regulating waste from electrical and electronic equipment) set recycling and reuse targets which were relevant in conjunction to some plastics with brominated flame retardants (EC 2002).

More recently, decaBDE has been registered under the REACH regulation (in September 2010, based on the data from the previous EU risk assessment) and in 2012 it was placed on the so-called Candidate List, as a Substance of Very High Concern (SVHC). It thereby became a substance in need of potential authorisation and restriction, ${ }^{12}$ which in 2013 led the European Chemicals Agency to start preparing a restriction proposal (ECHA 2014).

Turning to environmental quality and the Water Framework Directive, the linked Priority Substance Directive originally set various environmental quality standards for surface water for 33 substances or groups of substances, which Member States were obliged to comply with as a main rule by 2015 (EC 2008b) and partly through means specified in the WFD. Among these substances, pentaBDE belonged to a subgroup of particular concern referred to as 'priority hazardous substances', whereas octaBDE and decaBDE were considered 'priority substances'. In the recent amendment of the directive, standards for PBDEs were both amended and widened to include biota, for which the requirements must be met by 2021 at the latest (EU 2013).

Just as for PCBs, the Marine Strategy Framework Directive (EC 2008a) includes descriptors that cover PBDEs, and based on monitoring programmes and a programme of measures to be implemented by 2015-2016, the overall target of 'good environmental status' is supposed to be reached by 2020. In the context of the Baltic Sea, this work is coordinated by HELCOM and linked to the implementation of BSAP.

\footnotetext{
${ }^{10}$ Not restricting decaBDE was based on the recommendation of the EU 2002 risk assessment report, written by France and the UK, which stated environmental risks to be acceptable, partly based on the view that decaBDE did not bioaccumulate, even though the report recommended monitoring and further health-related studies. In addition, industry committed to reduce emissions. When the report was updated with the same general conclusion in 2004, it was criticised by the Commission's advisory Scientific Committee on Health and Environmental Risks (see further in SCHER 2005; Eriksson et al. 2010b).

${ }^{11}$ Since then, the ROHS directive has been further amended.

${ }^{12}$ UK submitted an Annex XV Dossier to ECHA proposing decaBDE as a SVHC.
} 


\subsubsection{HELCOM Policy}

By the time brominated flame retardants started to be targeted by policymakers, the Helsinki Convention had been amended, requiring the Parties 'to prevent and eliminate pollution of the marine environment of the Baltic Sea Area caused by harmful substances from all sources'. Compared to the 1974 convention, the 1992 version is more stringent and comprehensive. One example is that the 1974 Annex II list of 'noxious substances and materials' has been broadened to a 1992 Annex I list of 'Priority groups of harmful substances', where, for example, (all) 'organohalogen compounds' are included, as opposed to only 'persistent halogenated hydrocarbons' in 1974, meaning that now all PBDEs are definitely covered at least indirectly.

In the mentioned 1998 Recommendation (19/5) on the 2020 target, brominated flame retardants were included in the list of 280 substances of potential concern, but neither the BFR-group as a whole nor organohalogens and PBDEs were among the 42 substances prioritised for immediate action. However, explicit reference to PBDEs was repeatedly made in the 2007 Baltic Sea Action Plan (HELCOM 2007), which updated the Recommendation. PentaBDE and octaBDE were targeted for use, production and marketing bans by 2010, whereas decaBDE could be a target from 2009 for less stringent measures, in some sectors, if further assessments showed a need for taking such action. All three PBDEs were included in a group of 11 substances of 'specific concern' to the Baltic Sea.

Moreover, 3 years later, when the 1990 Recommendation (19/5) was updated, all three - penta, octa and decaPBDE - were included in the list of priority hazardous substances, against which measures should be focused (HELCOM 2010c).

\subsubsection{Analysis of Measures Taken and Approaches Applied}

According to HELCOM, the PBDE levels in, for example, fish and guillemots are generally higher in almost all monitored areas in the Baltic Sea than what is defined to be a Good Environmental Status (Nyberg et al. 2013a). At the same time, the concentrations of some individual PBDEs are decreasing, which has been claimed to be a result of the EU restrictions in place since 2004, even though data is missing for some marine areas (Nyberg et al. 2013a). It thus seems plausible that the legal measures against pentaBDE and octaBDE have given results. However, since many products with PBDEs remain in use and since the restrictions have not targeted decaBDE, which as such is a problematic substance and in addition can be degraded in the environment into, for example, pentaBDE, the environment is still affected by this group of brominated flame retardants. It is moreover evident that it took a long time for measures to be implemented, in particular those for decaBDE. Even if the time between substance introduction and policy-making is far from as long in total as for PCBs, the general awareness of chemical risks - and the science-policy arsenal available - was much stronger after the 1980s than in the 1960s, so it could well 
be argued that society responded comparatively slower on PBDEs than on PCBs. When measures were agreed though, the regulatory strength of the EU was much greater than in the 1960s, even though the complex science-policy interface in EU legislation, placing a very strong burden of proof for measures, led to significant policy delays. ${ }^{13}$

When it comes to the policy approach, the PBDE group has been regulated mainly on the basis of the chemicals and polluter-oriented policy, not based on an environmental approach, and even less so on a precautionary approach. The latter is particularly true for decaBDE, where action was stalled during lengthy and politicised decision-making and legal processes (Eriksson et al. 2010a, 2010b). The environment-oriented approaches in the case of MSFD, for example, have so far not led to significant phase-out measures in themselves, and there are obvious implementation problems. In the case of WFD, in its third implementation report, the European Commission was unable to even establish a baseline for the chemical status of surface waters due to data gaps and insufficient monitoring (more than 40 $\%$ of surface water bodies in the EU were reported as having 'unknown chemical status') making it very difficult to estimate the EU-wide or Baltic Sea situation (European Commission 2012). Similarly, while BSAP is based on EAM (in theory linking hazardous substances, negatively, to biodiversity objectives on the one hand and to eutrophication on the other, where goal achievement may lead to higher concentrations of pollutants in biota), the practical responses to these insights still have to be implemented broadly. Nevertheless, BSAP sets out to link the work of HELCOM-identified substances to the national implementation plans under WFD, thereby helping policy efficiency in practice. More generally, the implementation of BSAP may help to broaden the implementation of WFD in EU Member States, and conversely, some environment-oriented EU policies may then be implemented in the HELCOM context. As for PCBs, there is thus a positive interplay between EU and HELCOM policies, when it comes to BFRs.

\subsection{The Third Generation, Perfluorinated Organic Substances: PFOS and PFOA}

Man-made fluorinated organic chemicals are since long widely used in industrial processes and commercial products and are commonly detected in organisms and various environmental compartments, the most well-known case being the infamous chlorofluorocarbons that have depleted the ozone layer (e.g. EEA 2001). One complex group of fluorinated organohalogens consists of perfluorinated substances, which, due to not least their stability and surface-active properties, are commonly used since the 1950s in, for instance, firefighting foam, non-stick coatings, food packaging and electronics, as well as for water and stain proofing in textiles and

\footnotetext{
${ }^{13}$ Comprehensive policies for destruction and decontamination of products containing PBDEs, as exist for PCBs, are still largely missing for PBDEs (see, e.g. Bergman 2012).
} 
shoes, used both as sprays and as components in garments and leather (Giesy and Kannan 2002; Lindstrom et al. 2011). While not all perfluorinated substances are necessarily problematic, some are indeed so. For instance, PFOS (perfluorooctane sulphonate) and PFOA (perfluorooctanoic acid) have at least since 2000s been targets of public policy (Renner 2001).

Several perfluorinated substances belonging to the group of perfluoroalkylated substances (PFAS) are persistent, bioaccumulative and toxic (Scheringer et al. 2014). PFOS and PFOA belong to the PFAS group, are both substances in use in themselves and common degradation products of hundreds of other perfluorinated substances and are extremely persistent and therefore detected around the globe, including in the Arctic environment, in Europe and the Baltic Sea (Butt et al. 2010; Holmström et al. 2005; Lau et al. 2007; Letcher et al. 2010; Nyberg et al. 2013b; Pistocchi and Loos 2009).

PFOS meets the criteria in the EU REACH regulation of being very persistent and at least bioaccumulative (RPA 2004). It also biomagnifies and is commonly found in, for instance, polar bears in the Arctic (Greaves and Letcher 2013) as well as in fish and seals in the Baltic Sea (Kratzer et al. 2011; Schuetze et al. 2010). PFOA is also very persistent and bioaccumulates in at least air-breathing mammals, including humans (ECHA 2013) ${ }^{14}$ the first findings of such bioaccumulation being reported as early as the 1970s (Lindstrom et al. 2011). Even if there is vast uncertainty regarding the properties and effects of most substances in the PFAS group, PFOS has been classified as toxic, and animal experiments have shown negative effects of it on, for example, reproduction, endocrine systems, the liver, the immune system and the nervous system (Austin et al. 2003; Johansson et al. 2008; Lau et al. 2007). For birds of prey, observed concentrations may be close to those where effects in the environment might be seen (Nyberg et al. 2013b). Humans are exposed via water and food, such as fish (Borg and Håkansson 2012), and various hormonal and reproductive effects and risks on humans have been shown (Lopez-Espinosa et al. 2011; Lopez-Espinosa et al. 2012). PFOA has also been classified as toxic from different points of view, among these as a suspected carcinogen and toxic for reproduction (UNEP 2006; ECHA 2013). Recent studies show even more worrying signs regarding cancer (Barry et al. 2013).

\subsubsection{EU Policy}

In the EU, a process to restrict PFOS was started in 2005 by the European Commission, based on an OECD hazard assessment as well as the EU risk assessment report under the previous existing substance programme (European Commission 2005). In the following co-decision procedure, the European Parliament proposed, agreeing across party lines, to extend the Commission's proposal to

\footnotetext{
${ }^{14}$ Strangely, in spite of this judgment from ECHA, the researchers reporting on HELCOM core indicators did not consider PFOA to be bioaccumulative (Nyberg et al. 2013b).
} 
restrict PFOS to include PFOA as well. This proposal was motivated with a reference saying that the US EPA had found the risks of the latter substance to be of 'similar concern' (European Parliament 2006). After an unusually rapid legislative process, the Parliament and Council then agreed on a directive that was more restrictive than the Commission's proposal on general limit values for PFOS in products and against firefighting foams, but did not regulate PFOA, as the Parliament had proposed (EC 2006c). The restriction was eventually moved over to the REACH regulation when it entered into force and then to EU's so-called POPs regulation (EU 2010b)..$^{15}$

PFOA, as mentioned above, was not restricted in the EU co-decision procedure, but it was said that the European Commission shall keep substitutes and ongoing risk assessment activities under review and propose risk-reducing measures when needed (EC 2006c). Presently, PFOA is on the REACH Candidate List as a Substance of Very High Concern, which means that it eventually might be a target for an authorisation process (ECHA 2013).

Turning to environmental quality, PFOS was included in WFD and the Priority Substance Directive after it was revised recently. The Priority Substance Directive required Member States to implement stated quality standards by 2018 and attain a good surface water chemical status by 2027 at the latest (EU 2013). The quality standard is based on the most sensitive parameter for PFOS, namely, secondary poisoning (KEMI 2013b). In MSFD, one of the descriptors (number 8) covers PFOS, and on that basis, Member States shall define precise targets for a 'good environmental status' to reach by 2020 at the latest, through programmes to be implemented in 2015-2016 at the latest (EC 2008a). No similar environmental quality stipulations exist for PFOA.

\subsubsection{HELCOM Policy}

PFOS was included in the work of HELCOM in particular after BSAP was adopted in 2007. In the plan, the Parties agreed to 'start by 2008 to work for strict restrictions on the use in the whole Baltic Sea catchment area of the Contracting States of... perfluorooctane sulfonate (PFOS)'. PFOA was also included in BSAP in the same manner as decaBDE, namely, that by 2009 , 'if relevant assessments show the need' to initiate adequate measures in some sectors, for instance, use restrictions (HELCOM 2007). PFOS and PFOA were both listed among the 11 substances of 'specific concern' in BSAP and in the most recent Recommendation (31E/1) listing 'priority hazardous substances' (HELCOM 2010c), but only PFOS later became a HELCOM Core indicator (HELCOM 2013b).

\footnotetext{
${ }^{15}$ PentaBDE was included at the same time. In simultaneous amendment of Annex IV and V of the same regulation (http://eur-lex.europa.eu/LexUriServ/LexUriServ.do?uri=OJ:L:2010:223:0020:0 028:EN:PDF), new provisions regarding waste management also came.
} 


\subsubsection{Analysis of Measures Taken and Approaches Applied}

When it comes to PFOS, the concentrations in the Baltic Sea have increased since the 1960s, in some case exponentially (Holmström et al. 2005). Even if there are a few recent signs of decline, PFOS levels exceed the thresholds in many monitoring sites, 'indicating moderate or even bad environmental status', with the highest PFOS levels in biota found in top consumers such as grey, harbour and ringed seals (Nyberg et al. 2013b). Much data on temporal trends is missing, and to what extent PFOS levels really have started to decline in, for example, the Baltic Sea is therefore far from certain. Decreased levels in human blood have, however, been reported in the USA in the 2000s, allegedly following the dominating producer 3 M-Corporations voluntary measure started in 2000 to phase out PFOS and related chemicals (Renner 2008). Less is known about temporal development of PFOA in the Baltic Sea, and trends can of course point in different directions depending on if emissions, water concentrations or levels in biota are studied, with variations between regions and species. Nevertheless, despite a downturn in emissions, also due to a voluntary phase-out by large producers ('the PFOA Stewardship programme'), levels of PFOA in the Arctic sea water have been predicted to continue to increase until around 2030, whereas the situation has been predicted to improve in the Northern Temperate zone in the 2010s (Butt et al. 2010).

From a regulatory point of view, the legislative process to restrict PFOS in the EU was comparatively rapid, even if it - as so often otherwise - was initiated long after science indicated problems existed. Here, the EU has been the dominating phase-out force, whereas HELCOM has focused more on principal policy advice and assessment, seemingly in the aftermath of the EU legislative process (whereas HELCOM policy and assessments were ahead of legislation when it comes to PCBs). Moreover, regulatory action took place in particular in the sphere of chemicals policy and was not based on environment-oriented legislation. Partly, the rapid regulatory process can of course be attributed to the fact that many industries had beforehand already promised a voluntary phase-out. Given that production-related emissions for these reasons will cease or at least continue to decline, it is difficult to predict which roles MSFD and PSD will play in this particular case in the future. Perhaps, MSFD's focus on environmental quality might speed up the upstream work so that increased focus on disposal and sanitation might follow, in order to try to cope with still existing products in use.

Public policy has not focused on PFOA as it has on PFOS, and despite sciencebased identification of problems with PFOA, restrictions are still not in place. Here, HELCOM has taken a more pioneering role in terms of policy direction, but it remains to be seen what that will lead to; HELCOM parties are not taking countrybased measures to the same extent after EU enlargement and the REACH regulation as they (at least some of them) did before. ${ }^{16}$ In many ways, PFOA seems to have

\footnotetext{
${ }^{16}$ Some EU Member States' initiatives regarding BPA and decaBDE show that national measures are not completely impossible in an EU harmonised policy arena.
} 
been considered in a similar way to decaBDE in the case of PBDEs, i.e. showing potentially less worrying properties and therefore being given, at most, secondary attention in the policy process. From a broader point of view, it also remains to be seen to what extent the use of other perfluorinated substances with similar hazardous properties will increase, following the phase-out of PFOS and, potentially, PFOA. Science-based concerns are not necessarily smaller in those cases (Scheringer et al. 2014).

\subsection{Discussion}

This study has focused on how public risk governance of three generations (chlorinated, brominated, fluorinated) of hazardous chemicals and specific examples linked to these (PCBs, PBDEs, PFOS/PFOA) has developed in BSR over time, with a special focus on the EU and HELCOM.

Indeed, both the EU and HELCOM have responded with various types of legislation, recommendations and policies in order to manage the problems and risks caused by these substances. In general, the response has been more reactive than proactive, but when the stricter types of measures pointed out in the article once have been taken, both problems and risks have decreased over time, even though not to the extent needed in order to reach the overall objectives of a non-toxic environment.

If we look at the question of time, the regulatory response to societal debate might generally be seen as more rapid (or less slow) in recent years, than in the past, both in the EU and under the Helsinki Convention. Even if the fluorinated substances (third generation) have been in use for a long time, the EU and HELCOM have reacted more firmly in the PFOS case than in the PCB case. That is what could be expected given the more solid knowledge base and the higher environmental awareness today.

Still, given this improved state of knowledge and awareness on chemical risks, and given decades of recurring experiences of regulatory bottlenecks, one must ask if the decision-making processes in the EU are not unreasonably slow today. The question must even be raised if these processes might actually be comparatively slower than in the past. For example, the management of decaBDE (second generation) has been characterised by significantly stronger requirements than in the PCB case (first generation), to produce an overwhelming body of evidence, based on quite traditional risk assessment processes, despite the fact that history has shown this to be problematic and despite the fact that precaution nowadays is a part of the EU treaty as well as secondary law. ${ }^{17}$ Further scholarly studies on these and other substance cases are needed though, to be able to draw firm conclusions on the topic,

\footnotetext{
${ }^{17}$ The Treaty on the Functioning of the EU (TFEU 2007) and REACH (e.g. authorisation can be demanded for hazardous substances even without necessarily proving them to be toxic) include precautionary elements.
} 
including on whether the precautionary dimension that after all exists in REACH is counteracted by complex and slow implementation procedures so that the regulatory speed is even slower today than under the previous EU risk assessment programme for existing substances. A corresponding question needs to be asked also concerning HELCOM, which - despite more commonly than EU referring to the precautionary principle - has been quite reluctant to act on decaBDE and PFOA, albeit not to the same extent as the EU.

All in all, this regulatory reluctance signals a weak tradition and capacity in both institutions to cope with uncertainty, which may fuel sociopolitical controversy. For example, in the case of decaBDE assessment and regulation in the EU, divergent opinions on how to interpret available knowledge and remaining uncertainty opened the way for politicisation of the issue and consequently controversial regulatory and court processes. Without policy and regulatory reforms, which most importantly need to move towards a more fully reversed burden of proof, ${ }^{18}$ substantial difficulties will remain even in the future when managing hazardous chemicals and their environmental and health risks, thereby jeopardising the agreed objectives in e.g. BSAP. ${ }^{19}$

Turning from the dominating risk-based and polluter-oriented chemical regulations to the more environment-oriented directives and plans, such as MSFD and BSAP, they clearly stand for a more holistic perspective, being in line with EAM, often expressing precaution as important. From the aquatic starting point, these tools aim at addressing a number of substances based on environmental monitoring and stated limit values. Here as well, however, decaBDE and PFOA have been included at quite a late stage. Moreover, even if identified as being of concern, MSFD and BSAP as such do not lead to phasing out or restrictions on substances that are targeted. In addition, country-based implementation is far from effective. Despite observed regulatory hurdles such as the high burden of proof in EU chemicals policy, it is therefore still not certain that environment-oriented policies such as MSFD and BSAP are more efficient in promoting the agreed objectives of, for example, good environmental status.

Based on the reasoning above, it seems obvious that both policy orientations and approaches are needed and that they need to be better linked than today. Our case studies indicate that this coordination is required both in science (e.g. in terms of information and knowledge exchange between REACH and MSFD/BSAP) and management (e.g. by allowing fast-tracking in REACH of hazardous substances that show up in the marine environment or by triggering upstream sanitation measures if prohibited hazardous substances continue to show up in the environment as result of leakage from already introduced products in society). In addition, starting from EAM, both MSFD and BSAP should reasonably be developed to include mechanisms for addressing groups of similar hazardous substances and other types

\footnotetext{
${ }^{18}$ For example, the reversed burden of proof in REACH concerns substance registration but not, for example, restrictions (see further in Karlsson 2010).

${ }^{19}$ See, e.g. Karlsson et al. (2011) and Karlsson (2010) for more detailed ideas on governance reforms.
} 
of problematic mixtures. In particular, when evidence of continuing problems with regard to halogenated substances is as strong as it is, illustrated in this study with a few examples, the EU and HELCOM need to implement chemical group perspectives, if the objective of a non-toxic environment is to be reached. Science gives stronger support to the default assumption that similar types of substances within a group - let it be chlorinated, brominated or fluorinated, as well as organohalogens show significantly similar properties than to the default assumption that these substances would have substantially different properties. A broader group-based perspective in chemicals and environmental policy would also allow for much more rapid regulatory processes, promoting the overall objectives in place.

Finally, looking ahead, it is clear that the EU over time has emerged as the strongest policy-making body in the governance of hazardous chemicals in BSR. However, HELCOM still plays an important role for monitoring and environmentally based assessments, as well as for the conceptual framing of measures and appropriate strategies. The EU and HELCOM should be seen to be complementary, more or less well coordinated in different parts of the region, rather than as competing institutions. ${ }^{20}$ Europeanisation and regionalisation can be synergetic trends, given the right set-up.

Acknowledgements This research was funded by the Foundation for Baltic and East European Studies and the European Community's Seventh Framework Programme (2007-2013) under grant agreement $\mathrm{n}^{\circ} 217246$ made with the joint Baltic Sea research and development programme BONUS, as well as by the Swedish Environmental Protection Agency and the Swedish Research Council FORMAS. We wish to thank these institutions for enabling this research. Two peer reviewers are also thanked for valuable comments on an earlier version of the chapter.

Open Access This chapter is distributed under the terms of the Creative Commons AttributionNoncommercial 2.5 License (http://creativecommons.org/licenses/by-nc/2.5/) which permits any noncommercial use, distribution, and reproduction in any medium, provided the original author(s) and source are credited.

The images or other third party material in this chapter are included in the work's Creative Commons license, unless indicated otherwise in the credit line; if such material is not included in the work's Creative Commons license and the respective action is not permitted by statutory regulation, users will need to obtain permission from the license holder to duplicate, adapt or reproduce the material.

\section{References}

Adger WN, Jordan A (eds) (2009) Governing sustainability. Cambridge University Press, Cambridge

Airaksinen R, Hallikainen A, Rantakokko P, Ruokojärvi P, Vuorinen PJ, Parmanne R, Verta M, Mannio J, Kiviranta H (2014) Time trends and congener profiles of PCDD/Fs, PCBs, and

\footnotetext{
${ }^{20}$ In addition, HELCOM includes, e.g. Russia, which is evidently important to be included in the cooperation in order to promote the targets set up.
} 
PBDEs in Baltic herring off the coast of Finland during 1978-2009. Chemosphere 114:165-171

Allanou R, Hansen BG, van der Bilt Y (1999) Public availability of data on EU high production volume chemicals. European Commission, European Chemicals Bureau, Ispra

Austin ME, Badrinarayanan SK, Barber M, Kurunthachalam K, MohanKumar PS, MohanKumar SMJ (2003) Neuroendocrine effects of perfluorooctane sulfonate in rats. Environ Health Perspect 111:1485-1489

Backer H, Leppänen JM, Brusendorff AC, Forsius K, Stankiewicz M, Mehtonen J, Pyhälä M, Laamanen M et al (2010) HELCOM Baltic Sea Action Plan. A regional programme of measures for the marine environment based on the ecosystem approach. Mar Pollut Bull 60:642-649

Barry V, Winquist A, Steenland K (2013) Perfluorooctanoic acid (PFOA) exposures and incident cancers among adults living near a chemical plant. Environ Health Perspect 121:1313-1318

Bergman A (2007) Pathological changes in seals in Swedish waters: the relation to environmental pollution. Doctoral thesis, Swedish University of Agricultural Sciences, Uppsala

Bergman P (2012) Bättre EU-regler för en giftfri miljö (in Swedish). Rapport 1/12. KEMI, Stockholm

Bergman A, Olsson M (1985) Pathology of Baltic grey seal and ringed seal females with special reference to adrenocortical hyperplasia: is environmental pollution the cause of a widely distributed disease syndrome? Finn Game Res 44:47-62

Birnbaum LS, Staskal DF (2004) Brominated flame retardants: cause for concern? Environ Health Perspect 112:9-17

Boalt E, Nyberg E, Bignert A, Hedman J, Danielson S, the HELCOM CORESET expert group for hazardous substances (2013) Polychlorinated biphenyls (PCB) and dioxins and furans. HELCOM, Helsinki

Borg D, Håkansson H (2012) Environmental and health risk assessment of perfluoroalkylated and polyfluoroalkylated substances (PFASs) in Sweden. Report 6513. SEPA, Stockholm

Burkow IC, Kalleborn R (2000) Sources and transport of persistent pollutants to the arctic. Toxicol Lett 112-113:97-92

Butt CM, Berger U, Bossi R, Tomy GT (2010) Levels and trends of poly- and perfluorinated compounds in the arctic environment. Sci Total Environ 408:2936-2965

Carrera G, Fernandez P, Vilanova RM, Grimalt JO (2001) Persistent organic pollutants in snow from European high mountain areas. Atmos Environ 35:245-254

CBSS (1996) Kalmar Communiqué Council of the Baltic Sea States. Fifth Ministerial Session, Kalmar 2-3 July 1996

COHIBA (2012) Major sources and flows of the Baltic Sea Action Plan hazardous substances. WP4 final report. IVL, Stockholm

Curtin R, Prellezo R (2010) Understanding marine ecosystem based management: a literature review. Mar Policy 34:821-830

Darnerud PO, Eriksen GS, Johannesson T, Larsen PB, Viluksela M (2001) Polybrominated diphenyl ethers: occurrence, dietary exposure, and toxicology. Environ Health Perspect 109:49-68

de Wit CA (2002) An overview of brominated flame retardants in the environment. Chemosphere 46:583-624

EC (1986) Single European Act. OJ L 169:1-29

EC (1996) Council Directive 96/59/EC on the disposal of polychlorinated biphenyls and polychlorinated terphenyls (PCB/PCT). OJ L 243:31-35

EC (2000) Directive 2000/60/EC of the European Parliament and of the Council establishing a framework for community action in the field of water policy. OJ L 327:1-72

EC (2001) Council Regulation 2375/2001/EC of 29 November 2001 amending Commission Regulation 466/2001/EC setting maximum levels for certain contaminants in foodstuffs. OJ L $321: 1-5$

EC (2002) Directive 2002/96/EC of the European Parliament and of the Council on waste electrical and electronic equipment (WEEE). OJ L 37:24-39 
EC (2003a) Directive 2003/11/EC of the European Parliament and of the Council amending for the 24th time Council Directive 76/769/EEC relating to restrictions of certain dangerous substances and preparations (pentabromodiphenyl ether, octabromodiphenyl ether). OJ L 42:45-46

EC (2003b) Directive 2002/95/EC of the European Parliament and of the Council on the restriction of the use of certain hazardous substances in electrical and electronic equipment. OJ L37:19-23

EC (2004) Regulation (EC) No 850/2004 of the European Parliament and of the Council of 29 April 2004 on persistent organic pollutants and amending Directive 79/117/EEC. OJ L $158: 7-49$

EC (2006a) Regulation (EC) 1907/2006 of the European Parliament and of the Council concerning the Registration, Evaluation, Authorisation and Restriction of Chemicals (REACH). OJ L 396:1-849

EC (2006b) Commission Regulation 1881/2006/EC setting maximum levels for certain contaminants in foodstuffs. OJ L 364:5-24

EC (2006c) Directive 2006/122/EC of the European Parliament and of the Council amending for the 30th time Council Directive 76/769/EEC on restrictions of certain dangerous substances and preparations (perfluorooctane sulfonates). OJ L 372:32-34

EC (2008a) Directive 2008/56/EC of the European Parliament and of the Council establishing a framework for community action in the field of marine environmental policy (Marine Strategy Framework Directive). OJ L 164:19-40

EC (2008b) Directive 2008/105/EC of the European Parliament and of the Council on environmental quality standards in the field of water policy. OJ L 348:84-97

EC (2011) Commission Regulation 1259/2011/EU of 2 December 2011 amending Regulation EC $1881 / 2006$ as regards maximum levels for dioxins, dioxin-like PCBs and non dioxin-like PCBs in foodstuffs. OJ L 320:18-23

ECB (European Chemicals Bureau) (2000) European Union risk assessment report diphenyl ether, pentabromo deriv. Institute for Health and Consumer Protection, Joint Research Centre, European Commission

ECB (European Chemicals Bureau) (2002) European Union risk assessment report bis(pentabromodiphenyl) ether. Institute for Health and Consumer Protection, Joint Research Centre, European Commission

ECHA (European Chemicals Agency) (2013) Member State Committee support document for identification of pentadecafluorooctanoic acid (PFOA) as a substance of very high concern because of its CMR and PBT properties. ECHA, Helsinki

ECHA (European Chemicals Agency) (2014) Annex XV restriction report. Proposal for a restriction. Bis(pentabromophenyl)ether. ECHA, Helsinki

ECJ (2008) Joined cases C-14/06 and C-295/06

EEA (2001) Late lessons from early warnings: the precautionary principle 1896-2000. Environmental Issue Report No 22. European Environment Agency, Copenhagen

EEA (2013) Late lessons from early warnings: science, precaution, innovation. EEA Report No 1/2013. European Environment Agency, Copenhagen

EEC (1967) Council Directive 67/548/EEC on the classification, packaging and labelling of dangerous substances. OJ 196:1-98

EEC (1976a) Directive 76/769/EEC on restrictions of certain dangerous substances and preparations. OJ L 262:201-203

EEC (1976b) Council Directive 76/464/EEC on pollution caused by certain dangerous substances discharged into the aquatic environment. OJ L 129:23-29

EEC (1985) Council Directive 85/467/EEC amending for the sixth time (PCBs/PCTs) Directive 76/769/EEC on restrictions of certain dangerous substances and preparations. OJ L 269:17-19

EEC (1993) Council Regulation 793/93/EEC on the evaluation and control of the risks of existing substances. OJ L 84:1-75 
Eriksson P, Jakobsson PE, Fredriksson A (2001) Brominated flame retardants: a novel class of developmental neurotoxicants in our environment? Environ Health Perspect 109:902-908

Eriksson P, Viberg PH, Jakobsson E, Orn U, Fredriksson A (2002) A brominated flame retardant, $2,2^{\prime}, 4,4^{\prime}, 5$-pentabromodiphenyl ether: uptake, retention, and induction of neurobehavioral alterations in mice during a critical phase of neonatal brain development. Toxicol Sci 67:98-108

Eriksson J, Karlsson M, Reuter M (2010a) Technocracy, politicization, and non-involvement: politics of expertise in the European regulation of chemicals. Rev Policy Res 27:167-185

Eriksson J, Karlsson M, Reuter M (2010b) Scientific committees and EU policy: the case of SCHER. In: Eriksson et al (eds) Regulating chemical risks: European and global challenges. Springer, Dordrecht

Eskenazi B, Chevrier J, Rauch SA, Kogut K, Harley KG, Johnson C, Trujillo C, Sjödin A, Bradman A (2013) In utero and childhood polybrominated diphenyl ether (PBDE) exposures and neurodevelopment in the CHAMACOS study. Environ Health Perspect 121:257-262

EU (2010a) Commission Decision 2010/477/EU on criteria and methodological standards on good environmental status of marine waters. OJ L 232:14-24

EU (2010b) Commission Regulation (EU) 757/2010 amending Regulation (EC) No 850/2004 of the European Parliament and of the Council on persistent organic pollutants as regards Annexes I and II. OJ L 223:29-36

EU (2013) Directive 2013/39/EU of the European Parliament and of the Council amending Directives 2000/60/EC and 2008/105/EC as regards priority substances in the field of water policy. OJ L 226:1-17

European Commission (1994) Regulation 1488/94/EC laying down the principles for the assessment of risks to man and the environment of existing substances in accordance with Council Regulation 793/93/EEC. OJ L 161:3-11

European Commission (2001) Communication from the Commission to the Council, the European Parliament and the Economic and Social Committee. Community strategy for dioxins, furans and polychlorinated biphenyls. (COM(2001) 593 FINAL

European Commission (2005) Proposal for a Directive of the European Parliament and of the Council relating to restrictions on the marketing and use of perfluorooctane sulfonates (amendment of Council Directive 76/769/EEC). COM(2005) 618

European Commission (2009) European Union Strategy for the Baltic Sea Region. Communication from the Commission to the European Parliament, the Council, the European Economic and Social Committee and the Committee of the Regions. COM(2009) 248 FINAL

European Commission (2012) Report from the Commission to the European Parliament and the Council on the implementation of the Water Framework Directive (2000/60/EC). Commission Staff Working Document (2/2). SWD(2012) 379 FINAL

European Parliament (2006) Report on the proposal for a directive of the European Parliament and of the Council relating to restrictions on the marketing and use of perfluorooctane sulfonates. (COM(2005)0618 - C6-0418/2005-2005/0244(COD)). A6-0251/2006

Gerecke AC, Hartmann PC, Heeb NV, Kohler HPE, Giger W, Schmidt P, Zennegg M, Kohler M (2005) Anaerobic degradation of decabromodiphenyl ether. Environ Sci Technol 39:1078-1083

Giesy JP, Kannan K (2002) Perfluorochemical surfactants in the environment. Environ Sci Technol 36:146A-152A

Gilbert N (2011) Data gaps threaten chemicals safety law. Nature 475:150-151

Greaves AK, Letcher RJ (2013) Linear and branched perfluorooctane sulfonate (PFOS) isomer patterns differ among several tissues and blood of polar bears. Chemosphere 93:574-580

Helander B (1983) Reproduction of the white-tailed sea eagle Haliaeetus albicilla (L.). In: Sweden, in relation to food and residue levels of organochlorine and mercury compounds in the eggs. Academic thesis, Stockholm, Gotab

HELCOM (1982) Recommendation (3/1) regarding the limitation of the use of PCB's

HELCOM (1985) Recommendation (6/1) regarding the elimination of the use of PCBs and PCTs

HELCOM (1988) Declaration on the protection of the environment of the Baltic Sea. Helsinki, 15 February 1988 
HELCOM (1998) Recommendation 19/5. HELCOM objective with regard to hazardous substances

HELCOM (2004) Recommendation 25/1 (Supersedes HELCOM Recommendation 6/1). Elimination of PCBs and PCTs

HELCOM (2007) Baltic Sea Action Plan. Adopted at HELCOM Ministerial Meeting, Krakow, Poland 15 November 2007

HELCOM (2010a) Hazardous substances in the Baltic Sea. An integrated thematic assessment of hazardous substances in the Baltic Sea. Proceeding 120B

HELCOM (2010b) HELCOM Ministerial Declaration on the implementation of the HELCOM Baltic Sea Action Plan. Moscow 20 May 2010

HELCOM (2010c). Recommendation 31E/1 (Supersedes HELCOM Recommendation 19/5). Implementing HELCOM's objective for hazardous substances

HELCOM (2013) HELCOM monitoring and assessment strategy

HELCOM, OSPAR (2003) Statement on the ecosystem approach to the management of human activities. First joint ministerial meeting of the Helsinki and OSPAR Commissions, Bremen, 25-26 June 2003

Helsinki Convention (1974) Convention on the protection of the marine environment of the Baltic Sea area

Helsinki Convention (1992) Convention on the protection of the marine environment of the Baltic Sea area

Herbstman JB, Sjödin A, Kurzon M, Lederman SA, Jones RS, Rauh V, Needham LL, Tang D, Niedzwiecki M, Wang RY, Perera F (2010) Prenatal exposure to PBDEs and neurodevelopment. Environ Health Perspect 118:712-719

Holmström KE, Järnberg U, Bignert A (2005) Temporal trends of PFOS and PFOA in guillemot eggs from the Baltic Sea, 1968-2003. Environ Sci Technol 39:80-84

Ilonka A, Meerts TM, van Zanden JJ, Luijks EAC, van Leeuwen-Bol I, Marsh G, Jakobsson E, Bergman $\AA$ (2000) Potent competitive interactions of some brominated flame retardants and related compounds with human transthyretin in vitro. Toxicol Sci 56:95-104

Jensen S (1966) Report of a new chemical hazard. New Sci 32:612

Jensen GK (2014) Health costs in the European Union. How much is related to EDCs? HEAL, Brussels

Joas M, Jahn D, Kern K (2008) Governance in the Baltic Sea region: balancing states, cities and people. In: Joas M, Jahn D, Kern K (eds) Governing a common sea. Environmental policies in the Baltic Sea region. Earthscan, London

Johansson N, Fredriksson P, Eriksson P (2008) Neonatal exposure to perfluorooctane sulfonate (PFOS) and perfluorooctanoic acid (PFOA) causes neurobehavioural defects in adult mice. Neuro Toxicol 29:160-169

Karlsson M (2010) The precautionary principle in EU and U.S. chemicals policy: a comparison of industrial chemicals legislation. In: Eriksson J, Gilek M, Rudén C (eds) Regulating chemical risks: European and global challenges. Springer, Dordrecht

Karlsson M, Gilek M, Udovyk O (2011) Governance of complex socio-environmental risks: the case of hazardous chemicals in the Baltic Sea. AMBIO 40(2):144-157

KEMI (Swedish Chemicals Agency) (2013a) Economic cost of fractures caused by dietary cadmium exposure. Report 4/13. KEMI, Stockholm

KEMI (Swedish Chemicals Agency) (2013b) Brandskum som möjlig förorenare av dricksvattentäkter (in Swedish). PM 5/13. KEMI, Stockholm

Kern K, Löffelsend T (2008) Governance beyond the nation states: transnationalization and Europeanization of the Baltic Sea region. In: Joas M, Jahn D, Kern K (eds) Governing a common sea. Environmental policies in the Baltic Sea region. Earthscan, London

Kooiman J (ed) (2003) Governing as governance. Sage, London

Kortenkamp A, Backhaus T, Faust M (2009) State of the art report on mixture toxicity. Final report of a project on mixture toxicology and ecotoxicology commissioned by the European Commission, DG Environment 
Kratzer J, Ahrens L, Roos A, Bäcklin BM, Ebinghaus R (2011) Temporal trends of polyfluoroalkyl compounds (PFCs) in liver tissue of grey seals (Halichoerus grypus) from the Baltic Sea, 1974-2008. Chemosphere 84:1592-1600

Lau C, Anitole K, Hodes C, Lai D, Pfahles-Hutchens A, Seed J (2007) Perfluoroalkyl acids: a review of monitoring and toxicological findings. Toxicol Sci 99:366-394

Law RJ, Allchin CR, de Boer J, Covaci A, Herzke D, Lepom P, Morris S, Tronczynski J, de Wit CA (2006) Levels and trends of brominated flame retardants in the European environment. Chemosphere 64:187-208

Letcher RL, Bustnes JO, Dietz R, Jensse BM, Jorgensen EH, Sonne C, Verreault J, Vijayan MM, Gabrielsen GW (2010) Exposure and effects assessment of persistent organohalogen contaminants in arctic wildlife and fish. Sci Total Environ 408:2995-3043

Lindberg P, Sellström U, Häggberg L, de Wit CA (2004) Higher brominated diphenyl ethers and hexabromocyclododecane found in eggs of peregrine falcons (Falco peregrinus) breeding in Sweden. Environ Sci Technol 38:93-96

Lindstrom AB, Strynar MJ, Libelo EL (2011) Polyfluorinated compounds: past, present, and future. Environ Sci Technol 45:7954-7961

Linduska JP (1953) DDT. Det vilda måste skyddas mot insektsgifterna (in Swedish). Sveriges Natur 6. Svenska Naturskyddsföreningen, Stockholm

Looser R, Froescheis O, Cailliet GM, Jarman WM, Ballschmiter K (2000) The deep-sea as a final global sink for semi-volatile persistent organic pollutants? Part II. Chemosphere 40:661-670

Lopez-Espinosa MJ, Fletcher T, Armstrong B, Genser B, Dhatariya K, Mondal D, Ducatman A, Leonardi G (2011) Association of perfluorooctanoic acid (PFOA) and perfluorooctane sulfonate (PFOS) with age of puberty among children living near a chemical plant. Environ Sci Technol 45:8160-8166

Lopez-Espinosa MJ, Mondal D, Armstrong B, Bloom MS, Fletcher T (2012) Thyroid function and perfluoroalkyl acids in children living near a chemical plant. Environ Health Perspect 120:1035-1041

Lyons G (1999) Chemical trespass: a toxic legacy. WWF-UK, London

Magnusson K, Norén K (2012) The sensitivity of the Baltic Sea ecosystem to hazardous compounds. PM 9/12. Swedish Chemicals Agency, Stockholm

MMB (Miljömålsberedningen) (2012) Minska riskerna med farliga ämnen. Strategi för Sveriges arbete för en giftfri miljö (in Swedish). Delbetänkande av MMB. SOU 2012:38. Fritzes, Stockholm

Murawski (AM) (2007) Ten myths concerning ecosystem approaches to marine resources management. Mar Policy 31:681-690

NCM (Nordic Council of Ministers) (2004) Cost of late action - the case of PCB. TemaNord 2004:556. NCM, Copenhagen

NCM (Nordic Council of Ministers) (2014) The cost of inaction. A socioeconomic analysis of costs linked to effects on endocrine disrupting substances on male reproductive health. Tema Nord. Nordic Council of Ministers, Copenhagen, p 557

Nyberg E, Bignert A, Danielsson S, Mannio J, the HELCOM CORESET expert group for hazardous substances (2013a) Polybrominated diphenyl ethers (PBDE). HELCOM, Helsinki

Nyberg E, Bignert A, Danielsson S, the HELCOM CORESET expert group for hazardous substances (2013b) Perfluorooctane sulphonate (PFOS). HELCOM, Helsinki

Österblom H, Gårdmark A, Bergström L, Müller-Karulis B, Folke C, Lindegren M, Casisni M, Olsson P et al (2010) Making the ecosystem approach operational. Can regime shifts in ecological and governance systems facilitate the transitions? Mar Policy 34:1290-1299

Pierre J, Peters BG (2005) Governing complex societies - trajectories and scenarios. Palgrave Macmillan, Basingstoke

Pistocchi A, Loos R (2009) A map of European emissions and concentrations of PFOS and PFOA. Environ Sci Technol 43:9237-9244

Pyhälä M, Brusendorff AC, Paulomäki H, Ehlers P, Kohonen T (2007) The precautionary principle and the Helsinki Commission. In: de Sadeleer N (ed) Implementing the precautionary principle. Earthscan, London 
Renner R (2001) Growing concern over perfluorinated chemicals. Environ Sci Technol $35: 154 \mathrm{~A}-160 \mathrm{~A}$

Renner R (2008) PFOS phaseout pays off. Environ Sci Technol 42:4618

Roos A, Greyerz E, Olsson M, Sandegren F (2001) The otter (Lutra lutra) in Sweden - population trends in relation to $\mathrm{DDDt}$ and total PCB concentrations during 1968-99. Environ Pollut 111:457-469

RPA (2004) Perfluorooctance Sulphonate. Risk reduction strategy and analysis of advantages and drawbacks. Final report. DEFRA, Norfolk

Rudén C, Hansson SO (2010) Registration, evaluation, and authorization of chemicals (REACH) is but the first step - how far will it take us? Six further steps to improve the European chemicals legislation. Environ Health Perspect 118:6-10

Rylander L, Strömberg U, Hagmar L (2000) Lowered birth weight among infants born to women with a high intake of fish contaminated with persistent organochlorine compounds. Chemosphere 20:1255-1262

Santillo D, Johnston P, Langston WJ (2001) Tributyltin (TBT) antifoulants: a tale of ships, snails and imposex. In: Harremoes P, Gee D, MacGarvin M, Stirling A, Keys J, Wynne B, Vaz G (eds) Late lessons from early warnings: the precautionary principle 1896-2000. Environmental issue report No 22. European Environmental Agency, Copenhagen, pp 135-148

Schantz SL, Gasior DM, Polverejan E, McCaffrey RJ, Sweeney AM, Humphrey HEB, Gardiner JC (2001) Impairments of memory and learning in older adults exposed to polychlorinated biphenyls via consumption of Great Lakes fish. Environ Health Perspect 109:605-11

SCHER (2005) Opinion on 'update of the risk assessment of bis(pentabromophenyl) ether (decabromodiphenylether)', Final environmental draft of May 2004. SCHER, European Commission, 18 March 2005

Scheringer M, Trier X, Cousins IT, de Voogt P, Fletcher T, Wang Z, Webster TF (2014) Helsing ør statement on poly- and perfluorinated alkyl substances (PFASs). Chemosphere 114:337-339

Schuetze A, Heberer T, Effkemann S, Juergensen S (2010) Occurrence and assessment of perfluorinated chemicals in wild fish from northern Germany. Chemosphere 78:647-652

Selin H, VanDeveer SD (2004) Baltic Sea hazardous substances management: results and challenges. AMBIO 33:153-160

SNFA (2011) Redovisning av regeringsuppdrag rörande gränsvärden för långlivade miljöföroreningar i fisk från Östersjöområdet (in Swedish). Dnr 115/2010. Swedish National Food Administration (SNFA), Uppsala

Stapleton HM, Alaee M, Letcher RJ, Baker JE (2004) Debromination of flame retardant decabromodiphenyl ether by juvenile carp (Cyprinus carpio) following dietary exposure. Environ Sci Technol 38:112-119

Szlinder-Richert J, Barska I, Usydus Z, Grabic R (2010) Polybrominated diphenyl ethers (PBDEs) in selected fish species from the southern Baltic Sea. Chemosphere 78:695-700

TFEU (2007) Consolidated versions of the Treaty on European Union and the Treaty on the Functioning of the European Union. OJ C 326:1-390

Udovyk O, Rabilloud L, Gilek M, Karlsson M (2010) Hazardous substances: a case study of environmental risk governance in the Baltic Sea region. RISKGOV report to BONUS EEIG Programme. Södertörn University, Sweden

UN (1992) United Nations convention on biological diversity

UNEP (United Nations Environment Programme) (2006) Risk profile on perfluorooctane sulphonate. Report of the Persistent Organic Pollutants Review Committee on the work of its second meeting. UNEP/POPS/POPRC.2/17/Add.5. Geneva, 6-10 Nov 2006

UNEP (United Nations Environment Programme) (2013) Costs of inaction on the sound management of chemicals

Ward MH, Colt JS, Deziel NC, Whitehead TP, Reynolds P, Gunier RB, Nishioka M, Dahl GV, Rappaport SM, Buffler PA, Metayer C (2014) Residential levels of polybrominated diphenyl ethers and risk of childhood acute lymphoblastic leukemia in California. Environ Health Perspect 122:1100-1116

Young OR (1994) International governance. Protecting the environment in a stateless society. Cornell University Press, New York 